\title{
Study for determining the presence of Brucella spp, Salmonella spp, E. coli 0157 and some other gram negative microorganisms in fresh cow's cheeses
}

\author{
Mehmet Emin Erkan ${ }^{1,}$, Simten Yesilmen², Aydın Vural ${ }^{1}$, Havin Bilgetekin ${ }^{3}$ \\ ${ }^{1}$ University of Dicle, Faculty of Veterinary Medicine, Department of Food Hygiene and Technology, Diyarbakir, Turkey \\ ${ }^{2}$ University of Dicle, Faculty of Veterinary Medicine, Department of Microbiology, Diyarbakir, Turkey \\ ${ }^{3}$ University of Rhenish Friedrich-Wilhelms, Faculty of Agriculture Department of Food Engineering, Bonn, Germany
}

\section{Email address:}

eminerkan@dicle.edu.tr (M. E. Erkan)

\section{To cite this article:}

Mehmet Emin Erkan, Simten Yesilmen, Aydın Vural, Havin Bilgetekin. Study for Determining the Presence of Brucella spp, Salmonella spp, E. coli O157 and Some other Gram Negative Microorganisms in Fresh Cow's Cheeses. International Journal of Nutrition and Food Sciences. Vol. 3, No. 5, 2014, pp. 443-447. doi: 10.11648/j.ijnfs.20140305.22

\begin{abstract}
This study was conducted to determine the presence of Brucella spp, Salmonella spp, E. coli O157 and some other gram negative microorganisms in fresh cow's cheeses (n:100). E. coli was determined in all of the samples, E. coli $O 157$ was found in 8 samples and Aeromonas hydrophila was found in 12 samples. In the analyzed cheeses the prevalences of Klebsiella pneumonia, Proteus mirabilis, Proteus vulgaris, Pseudomonas auroginosa, Citrobacter freundi and Morgonella morganni spp. siboni. were $16 \%, 16 \%, 7 \%, 16 \%, 12 \%$, and $10 \%$ respectively. Neither Salmonella spp. nor Brucella spp. were determined in any of the samples. In conclusion, it is our opinion that the hygienic qualities of fresh cow cheeses are low and they may constitute a public health risk.
\end{abstract}

Keywords: Brucella spp, E. coli O157, Fresh Cheese, Microbiological Quality, Gram Negative Microorganism

\section{Introduction}

Brucellosis commonly seen in human beings and animals in the Mediterranean countries, Middle East, Central Asia and South America $[1,2]$ is a zoonotic disease which is also called undulant fever, Mediterranean fever, Maltese fever and Bang's disease [3]. The disease causes abortions, loss of milk productivity and infertility in animals which are causes of economic losses. [4]. Brucellosis causes symptoms such as undulant fever, joint pain, muscle pain, abdominal pain, and headache $[1,5]$ which also leads physical ailments and loss of labor in human beings[3]. The most dangerous strain for human beings is Brucella melitensis; however B. suis, B. abortus, B.canis, B. pinnipedialis, $B$. ceti and $B$. innopinata are also known to cause infection. [1]. Infection spreads via direct contact with infected animals, laboratory accidents, consumption of infected food or inhalation of infectious particles [6]. $63.6 \%$ of human cases are reported to be due to the consumption of fresh milk and fresh milk products. [5] Brucellosis has a high morbidity but low mortality [3]. The prevalence of Brucella is reported between $0.6-22 \%$ in different regions of Turkey $[4,7,8]$.

Fresh cheeses are produced with traditional methods in rural areas, either in small establishments or in households. The milk might be the potential source of the Brucella spp. and other pathogenic microorganisms due to lack of pasteurization und salt treatment. The presence of pathogenic organisms such as Salmonella spp., E.coli, E.coli 0157 in food is a sign of direct or indirect fecal contamination and thusly poor hygienic conditions $[9,10]$. Aeromonas spp. are considered as an important food borne pathogenic organisms which can cause gastroenteritis [11] meningitis, wound infections and bacteremia in human beings [12] .Klebsiella spp. is an important opportunistic pathogenic organism. It can cause infections in the respiratory system, the nasal mucosa and the urinary tract [13]. Opportunistic pathogen bacteria such as Morgonella morganni spp. siboni and Proteus mirabilis can be dangerous for immunocompromised persons, the elderly 
and children $[14,15,16]$.

In this study the presence of Brucella spp, Salmonella spp, E. coli 0157 and some other gram negative microorganisms was determined in fresh cow's cheeses to find out possible dangers in terms of public health and food quality.

\section{Material and Methods}

\subsection{Collectiong the Samples}

In this study, 100 fresh cow's cheeses which were on the market in Diyarbakir/Turkey were examined. The sampled cheeses were produced by adding commercial rennet to fresh cow's milk at the temperature of milking. Heat treatment or suppression in brine was not utilized. 250 grams of samples were obtained under aseptically conditions from the cheeses which were on sale with no packaging and were brought to our laboratory with cold containers immediately.

\subsection{Isolation and Identification of Brucella spp}

10 gr of cheese sample were added in $90 \mathrm{ml}$ Farrell's broth and homogenized with a stomacher. Two $0.5 \mathrm{ml}$ dilute material obtaining from the homogenized samples were inoculated onto Farrel Broth in which Brucella Selective Supplement (Oxoid SR83) was added. One of the inoculated tubes was incubated in aerobic oven and another one in $10 \% \mathrm{CO}_{2}$ for 5 days at $37^{\circ} \mathrm{C}$. The tubes were vortexed everyday throughout the incubation period. At the end of the incubation periods, $0.1 \mathrm{ml}$ of enriched samples were obtained from each tube and inoculated onto Brucella Medium Base (Oxoid CM169). The aerobically inoculated samples were incubated in aerobic conditions and microaerophilically inoculated samples were incubated in microaerophilic conditions for 5 days at $37^{\circ} \mathrm{C}$. At the end of this period, 1-2 $\mathrm{mm}$ in diameter, pale yellow colored, transparent, round colonies on the Brucella Selective Agar were considered suspicious [17]. Brucella suspicious colonies were purified with Tryptic Soy Agar (Merck1.05458).The identification of colonies was carried out with a VITEK II automatic system device.

\subsection{Isolation and Identification of Aeromonas spp}

Preliminary enrichment process of 25 gram cheese samples was performed in sterile bags with $225 \mathrm{ml}$ of buffered peptone water (BPW, LAB204). After incubation at $37^{\circ} \mathrm{C}$ for $24 \mathrm{~h}$. one loop of the enriched fluid was inoculated with the streak method onto Aeromonas Agar (Oxoid CM 83) containing $5 \mathrm{mg} / \mathrm{l}$ Ampicilin (Oxoid SR 136). The plates were then incubated at $30^{\circ} \mathrm{C}$ for $24 \mathrm{~h}$. At the end of the incubation period, green opaque colonies with dark green centres on the Aeromonas Agar were considered suspicious. Suspicious colonies were purified with Tryptic Soy Agar (Merck-1.05458) and identification was carried out with a VITEK II automatic system device [18].

\subsection{Isolation and Identification of Pseudomonas spp}

The samples were inoculated on a Pseudomonas Agar Base (Merck 1.10989) and the petri dishes were incubated at $35^{\circ} \mathrm{C}$ for $5-7$ days. The resulting colonies were purified with Tryptic Soy Agar (Merck-1.05458) and identification was carried out with a VITEK II automatic system device [19].

\subsection{Isolation and Identification of Salmonella spp}

Preliminary enrichment process was applied to 25 grams of cheese samples in sterile bags added with $225 \mathrm{ml}$ of buffered peptone water (BPW, LAB204). $0.1 \mathrm{ml}$ of enriched fluid was obtained after incubation at $37^{\circ} \mathrm{C}$ for 24 $\mathrm{h}$ and selective enrichment was carried out in $10 \mathrm{ml}$ Rappaport-Vassiliadis Broth (RVS, LAB086). RVS tubes were incubated at $37^{\circ} \mathrm{C}$ for $24 \mathrm{~h}$. At the end of the incubation period, samples from these tubes were inoculated onto Xylose Lysine Deoxycholate Agar (XLD, LAB032) and incubated at $37^{\circ} \mathrm{C}$ for $24 \mathrm{~h}$. Pink colored and black centered colonies on the XLD agar were identified after the purification using Tryptic Soy Agar (Merck1.05458) with a VITEK II automatic system device [20].

\subsection{Isolation and Identification of E. coli and E. coli 0157}

For the isolation of E. coli, 10 grams of cheese samples were homogenized with $90 \mathrm{ml}$ of $0.09 \%$ sodium chloride and inoculated onto TBX (Tryptone Bile X-glucuronide) Agar (Merck-1.16122-0500). Colonies with the typical green color were processed with the Vitek 2 compact 15 device for identification. For the identification of $E$. coli O157, suspicious colonies were also verified with the latex agglutination test (oxoid E.coli DR 0620M ) [21].

\subsection{Isolation and Identification of Enterobacteriaceae}

VRBG (Violet Red Bile Glucose) Agar (Merck 1.10275) was used for the analysis of enterobacteriacea and the typical colonies obtained were passaged with EMB (Eosin Methylene-blue) Agar (Merck 1.01347). Positive samples were purified with Tryptic Soy Agar (Merck-1.05458) and identification was carried out with a VITEK II automatic system device [22].

\subsection{Determination of Antimicrobial Susceptibility}

Antibiogram testing was planned for pathogens (Brucella spp., Salmonella spp. and E. coli O157) which have the potential to cause serious disease in human beings. Since only E. coli O157 was isolated, antibiogram testing was done only for this bacterium.

Antimicrobial susceptibility testing of the isolates was done by the Kirby-Bauer disc diffusion method, according to Clinical Laboratory Standard Institute (CLSI M100-S20, 2012) protocol. All isolates were cultured on Muller Hinton agar added with $5 \%$ defibrinated sheep blood, and then all of them incubated microaerobically at $30^{\circ} \mathrm{C}$ for $48 \mathrm{~h}$. 
Bacterial colonies from fresh pure culture were mixed with Muller Hinton broth to prepare the turbidity of each inoculums was adjusted to McFarland 0.5 standards. Bacteria from each suspension were inoculated onto Muller Hinton agar using a sterile cotton-tipped swab. The plates were kept at $37^{\circ} \mathrm{C}$ for $1-2 \mathrm{~min}$, to get them dry, before antibiotic discs were dispensed. Incubation of the plates took place in a microaerobic atmosphere at $30^{\circ} \mathrm{C}$ for $48 \mathrm{~h}$ and the diameter of the inhibition zones was measured with calipers. The susceptibility patterns (resistancy/sensitivity) of the strains were determined according to the National Committee for Clinical Laboratory Standards [23].

\section{Results and Discussion}

The presence of Brucella spp., Salmonella spp., E. coli and E. coli $O 157$ was given in Table 1, the gram negative microorganisms detected were given in Table 2 and the antimicrobial susceptibility results of E. coli 0157 were given in Table 3. E. coli was found in every sample (100\%) whereas $E$. coli $O 157$ was found in $8 \%$ of the samples. No cases of Brucella spp or Salmonella spp. were detected. A. hydrophila was found in 5 samples.

All of the E. coli O157 isolates obtained from fresh cheeses were resistant to ampicillin, erythromycin, penicillin $G$ and spiramycin, on the other hand they were susceptible to ceftiofur, cefoperazone, gentamicin+amoxicillin, amoxicillin/clavulanic acid, enrofloxacin, nalidixic acid and streptomycin.

Table 1. Presence of Brucella Spp., Salmonella Spp., E. coli and E. coli O157 in Fresh Cheese Samples

\begin{tabular}{ll}
\hline Brucella spp. & not detected \\
Salmonella spp. & not detected \\
\hline E. coli & $100 \%$ \\
E. coli O157 & $8 \%$ \\
\hline
\end{tabular}

Table 2. Gram Negative Microorganisms Detected in Fresh Cheese Samples

\begin{tabular}{ll}
\hline Klebsiella pneumonia & 16 \\
\hline Proteus mirabilis & 16 \\
Proteus vulgaris & 7 \\
Pseudomonas auroginosa & 16 \\
Citrobacter freundi & 12 \\
Morgonella morganni spp. siboni & 10 \\
Aeromonas hidrophila & 12 \\
\hline
\end{tabular}

Table 3. Susceptibility of E. coli O157 Spp. to Antimicrobial Agents Isolated from Fresh Cheese

\begin{tabular}{llll}
\hline Antimicrobial & \multicolumn{3}{l}{ E. coli O157 (n=8) } \\
\cline { 2 - 4 } Agent, concentration $(\boldsymbol{\mu g}$ /disk) & $\mathbf{R}$ & $\mathbf{I}$ & $\mathbf{S}$ \\
\hline Penicillin/Novobiocin (40) & 6 & 2 & - \\
Ceftiofur (30) & - & - & 8 \\
Cefoperazone (30) & 6 & 2 & - \\
Cefoperazone (75) & - & - & 8 \\
Tetracycline (30) & 2 & - & 6 \\
Gentamicin+Amoxicillin (35) & - & - & 8 \\
Ampicillin (10) & 8 & - & - \\
Erythromycin (15) & 8 & - & - \\
Amoxicillin/clavulanic acid (30) & - & - & 8 \\
\hline
\end{tabular}

\begin{tabular}{llll}
\hline Antimicrobial & \multicolumn{3}{l}{ E. coli } \\
\cline { 2 - 4 } Ogent, concentration ( $(\boldsymbol{\mu g}=\mathbf{8} /$ disk) & $\mathbf{R}$ & $\mathbf{I}$ & $\mathbf{S}$ \\
\hline Enrofloxacin (5) & - & - & 8 \\
Penicillin G (10) & 8 & - & - \\
Spiramycin (100) & 8 & - & - \\
Doxycycline(30) & - & 2 & 6 \\
Nalidixic acid (30) & - & - & 8 \\
Streptomycin (25) & - & - & 8 \\
Trimethoprim/sulfamethoxazole (25) & 2 & - & 6 \\
\hline
\end{tabular}

In scientific studies the presence of a wide variety of bacteria such as Brucella spp. Salmonella spp., E.coli, E.coli O157, H7, Klebsiella spp., Proteus spp. in cheeses was reported. [24, 25, 26, 27, 28]. The presence of these bacteria indicates that cheese can be contaminated with human or animal sourced enteric bacteria. [10].

Brucellosis is a widespread [6] zoonotic infection which leads to economic losses due to abortion, loss of milk productivity and infertility [4]. Unpasteurized milk and milk products are important reasons in its spread [5, 9, 29]. There are differing results in studies which investigated the presence of Brucella spp. in cheeses. These differences in studies may depend on many factors such as regional differences, type of the cheese, production method or the utilization of heat treatment. In studies undertaken in Turkey, the presence of Brucella spp. was found to be 3.33$19.33 \%[28,29,30,32]$ for feta cheese, $1.81-20.5 \%$ for tulum cheese [28, 29, 31] and 17.5\% [9] for herbed cheese. In our study, Brucella spp. was not isolated in any of the cheese samples.

It is thought that the source of the milk, the vaccination status of the animals, the geographic region, heat treatment and the usage of salt in the production might influence the presence of Brucella spp. in cheeses. In the present study, the absence of Brucella spp. might be explained by the use of cow's milk, the vaccinated animals and the low incidence of Brucella spp. by cows in the region from where the cheese samples were obtained.

In this study, E. coli was detected in every sample investigated (100\%). These results are in accordance with the results obtained by Ordiales et al. [24] and Baz et al. [26). On the other hand Keskin et al. [32] notified the presence of $E$. coli in feta cheese samples as $86 \%$. In our study the mean number of $E$. coli was $1.6 \times 10^{6} \mathrm{cfu} / \mathrm{g}\left(1.2 \times 10^{2}-3.7 \times 10^{7}\right)$; whereas Ordiales et al. [24] detected the E. coli number in cheeses which were produced with fresh milk, on the second day as $1.1 \times 10^{5}-4.6 \times 10^{6} \mathrm{cfu} / \mathrm{g}$. Akkaya and Alişarlı [34] detected E. coli $0157: H 7$ in 1\% of feta cheese samples obtained from street markets in Afyonkarahisar city centre. Gümüşsoy, Gönülalan [35] and Baz et al. [26] did not detect any E. coli O157:H7 in fresh feta cheeses which they sampled. In our study, the presence of E. coli $O 157$ was determined at rate of $8 \%$. The presence of E. coli and E. coli O157:H7 is thought to be directly related to the hygienic conditions during milking, storage, processing of the milk and the production of the cheese. The cheeses examined in this study are considered to be exposed to fecal contamination in various stages of production. 
Salmonella spp. was not found in any of the sampled fresh cheeses. This Result is in accordance with the findings of Keskin et al. [33], Gülmez and Güven [35]. Akkaya and Alişarlı [26] found a $2 \%$ prevalence of Salmonella spp in feta cheese samples in their study. Uraz et al. [36] reported an $8.13 \%$ incidence of Salmonella spp. out of 81 samples of feta cheeses. Primary and secondary contaminations might have played a role in the results of Salmonella spp.

In the present study, in fresh cheese samples, gram negative bacteria which could be opportunistic pathogens were also isolated. It was reported in the study of Dülger and Gücin [25] that out of 264 isolates of fresh white cheese samples were found Klebsiella pneumoniae und Citrobacter spp at the rates of $5.69 \%$ and $11.75 \%$ respectively. In their study, Uraz et al. [36] reported, out of 81 isolates that were obtained from fresh white cheese samples, were determined Klebsiella pneumoniae at the rates of $1.16 \%$, Proteus mirabilis $2.32 \%$, Proteus vulgaris $1.16 \%$, Pseudomonas aeruginosa $1.16 \%$, Citrobacter freundi $3.49 \%$ and Aeromonas hidrophila 5.81\%. Massa et al. [37] reported in their study that was performed on mozarella cheeses out of 41 isolates, 37 cases of Klebsiella pneumoniae and 1 case of $E$. coli. In the present study the rates of gram negative bacteria were found to be higher. The variety and numbers of gram negative bacteria in cheeses could be related to hygienic conditions during production. These microorganisms have the potential of negatively influencing the quality and shelf life of cheeses.

\section{Conclusion}

In conclusion, it was detected that fresh cheeses did not contain Brucella spp. and Salmonella spp. but they were the sources for E. coli $O 157$ and other opportunistic gram negative bacteria. The presence of gram negative microorganisms indicates poor hygienic quality. The necessity of complying with hygiene rules at all stages from production to sales must be supported with training, legislation and inspection.

\section{References}

[1] A. Falenski, A. M. Scholl, M. Filter,C. Göllner,B. Appel, and K. Nöckler, "S Survival of Brucella spp. in mineral water, milk and yogurt,' International Journal of Food Microbiology 145, 1, pp.326-330, 2011

[2] G. Pappas, P. Papadimitriou, N. Akritidis, L. Christou, and E.V. Tsianos, 'The newglobal map of human brucellosis. The Lancet Infectious Diseases", 6, 91-99, 2006

[3] M. Cengiz, 'Bruselloz: 76 olgunun değerlendirilmesi,', Uzmanlık tezi, Şişli Etfal ve Araştırma Hastanesi. Enfeksiyon Hastalıkları ve Klinik Mikrobiyoloji, 2007

[4] M. Güllüce, A. Adıgüzel, and O..F. .Algur, ''Erzurum Bolgesinde Temin Edilen Ceşitli Peynir Orneklerinde Brucella Antijenlerinin ELISA ile Saptanması," Turk

\section{Mikrobiyol Cem Derg 33: 356-360, 2003}

[5] T. Buzgan, M. K. Karahocagil, H. Irmak, A. İ. Baran, H. Karsen, Ö. Evirgen, and H. Akdeniz 'Clinical manifestations and complications in 1028 cases of brucellosis: a retrospective evaluation and review of the literature Int J Infect Dis. Jun;14(6) 469-478, 2010

[6] M. K. Hacimustafaoğlu, ''Brucellozis,' The journal of current pediatrics. 2 pp. 39-43, 2004

[7] A. Muz, H. Ozer, H. Eroksuz, H.B. Ertaş, H. Öngör, H.B. Gülcü, M. Dabak, O. Başbuğ, and H. Kalender, 'Elazığ ve çevresinde koyun ve keçilerde abortus olgularının bakteriyolojik, serolojik ve patolojik olarak incelenmesi," Tr J Vet Anim Sci 23: 77, 1999

[8] H. Öngör, A. Muz, and B. Çetinkaya, '’Atık yapmış koyunlarda brusellozis'in teşhisinde ELISA ile diğer serolojik testlerin karşılaştırılması,', Tr. J. Vet. Anim. Sci., 25: 212001

[9] Y.C. Sancak, B. Boynukara, and H. Yardımcı, "Van otlu peynirlerinde Brucella'ların varlığı ve dayanma suresi uzerine bir araştırma," Veterinarium $4: 1,1993$

[10] A. Ünlütürk, and F. Turantaş, 'Gıda mikrobiyolojisi,', Mengi Tan Basımevi İzmir, 1999

[11] D. K. Papageorgiou, D. S. Melas, A. Abrahim, and K. Koutsoumanis," Growth and survival of Aeromonas hydrophila in rice puding (milk rice) during its storage at $4^{\circ} \mathrm{C}$ and $12^{\circ} \mathrm{C},{ }^{\prime}$ Food Microbiology 20, 385-390, 2003

[12] H. Daskalov, " The importance of Aeromonas hydrophila in food safety," Food Control., Volume 17, Issue 6, June Pages 474-483, 2006.

[13] A. M. A Mansour, H. M. Zaki, N. A. Hassan, and A. A. Al-Humiany, "Molecular Charecterization and İmmunoprotective Activity of capsular polysaccharide of Klebsiella pneumoniae isolated from Farm Animals at Taif governorate.' American Journal of Infectious Diseases 10 (1): $1-14,2014$

[14] B. W. Senior and S. Vörös, 'Protein profile typing- a new method of typing morganella morganii strains," J.Med.Microbiol. vol.33, 259-264, 1990

[15] Y. Wang, " Bacteria: Proteus, Encyclopedia of Food Safety," 486-489, 2014

[16] A. K. Halkman, 'Gida mikrobiyolojisi II ders notları', Ankara, 2013

[17] I. D. Farrel, 'The development of a new selective medium for the isolation of Brucella melitensis from contaminated sources" Research Veterinary Science, 16, 280-286.1974.

[18] S. A. Palumbo, C. Abeyta, and G. Stelma, "Aeromonas hydrophila Group. (Compendium of Methods for the Microbiological Examination of Fods. Third editon, Washington D.C. pp: 497-515, 1992

[19] FAO. Manual of Food Quality Control. 4. Rev. 1. "Microbiological Analysis". Food and Agricultural Organization of the United Nations, pp 43-56, 1992

[20] W.H. Andrews, G.A. June, P.S. Sherrod, T.S. Hammack, R.M. Amaguana Food and drug administration bacteriological analytical manual (pp. 5.01-5.20) (8th ed.)AOAC International, Gaithersburg, USA, 1995 
[21] ISO 16649-2, Microbiology of food and animal feeding stuffs-Horizantal method for the enumeration of betaglucuronidase-positive Escherichia coli - Part 2: Colonycount technique at 44 degrees $\mathrm{C}$ using 5-bromo-4-chloro3-indolyl beta D-glucuronideInternational Organization for Standardization, Geneva, 2001.

[22] Anon., 2004. ISO 21528-1:2004, Microbiology of food and animal feeding stuffs horizontal methods for the detection and enumeration of Enterobacteriaceae, Part 1: Detection and enumeration by MPN technique with preenrichment.

[23] Clinical and Laboratory Standards for Antimicrobial Susceptibility Testing; Sixteenth informational Supplement, CLSI Document M100- S20, CLSI, Wayne PA, 2012.

[24] E. Ordiales, M.J. Benito, A. Martín, R. Casquete, M.J. Serradilla, and M.G. Córdoba, 'Bacterial communities of the traditional raw ewe's milk cheese "Torta del Casar" made without the addition of a starter," Food Control 33, 448-454, 2013

[25] B. Dülger, and F. Gücin 'Bursa'da satışa sunulan taze beyaz peynirlerden izole edilen koliform grubu bakterilerin tanılanmas1,' Ekoloji Derg 8:17-20, 1999.

[26] E. Baz, M. Gülmez, A. Güven, C. Sezer, and B. Duman 'Kars ilinde satışa sunulan çiğ süt ve taze beyaz peynirlerin koliform grubu bakteri, E. coli ve E. coli O157:H7 yönünden incelenmesi,"' Kafkas Üni Vet Fak Derg 9:165167.2003

[27] L Akaya, and M. Alişarlı, ' 'afyon karahisarda satışa sunulan peynirlerde Listeria monocytogenes ve salmonella spp. varlığının belirlenmesi,'’YYU Vet Fak Derg.17 (1-2):87-91, 2006

[28] B. Patır and A.H. Dinçoğlu ' Elazığ'da Tüketime Sunulan Taze Beyaz Peynirler ile Tulum Peynirlerinde Brucella Spp. nin Varlığı Üzerine Araştırmalar,' Fırat Üniv., Sağlık Bilimleri Enst. Derg., 15 (1), 15 - 22, 2001
[29] R.Kara and L. Akkaya "Investigation of Brucella abortus and Brucella melitensis at Cheeses in Afyonkarahisar, Turkey"'British Journal of Dairy Sciences 3(1): 5-8, 2013

[30] A. Mert. 'Ankara yöresinde pazarlanan taze peynirlerde brucellanın varlığı üzerine araştırmalar,', Doktora tezi. Ankara üniversitesi Veteriner Fakültesi. 1984

[31] H. Kalender, C. Özcan, and N. Arslan, "Taze tulum peynirlerinde brucella izolasyonu," Türk Mikrobiyoloji cemiyeti dergisi. 31(34) 184-186, 2001

[32] M. Tunçbilek 1992, Ankara piyasasında satılan taze beyaz peynirlerin brucellozis riski yönünden incelenmesi. Yüksek lisans tezi.Ankara üniversitesi sağlık bilimleri enstitüsü.

[33] Y. Keskin, O. Özyaral, R. Başkaya, and M. A. Susur 'Semt pazarlarında satılan beyaz peynirlerin mikrobiyolojik kalitesinin araștırılması,'” Türk Mikrobiyol Cem Derg. 36:919,2006

[34] G. F. Gümüşsoy, and Z. Gönülalan ''Kayseri ilinde köy pazarında satılan peynirlerde enterohemorajik Escherichia coli O157:H7 suşunun araştırılması,', Sağllk Bil Derg $14: 13-9,2005$

[35] M. Gülmez, and Güven A. 'Beyaz ve çeçil peynirlerinde Campylobacter, Salmonella ve Listeria türlerinin araştırılması,'’ Kafkas Üni Vet Fak Derg 7:155-61, 2001

[36] G. Uraz, S. Bolat, E. Y1lmaz, and E. Sezgin, 'The distribution of enterobacteriaceae and some pathogenic micro-organisms in nonbranded white cheese samples sold in Ankara city" Internetional Journal of Dairy Tecnology, 62(2) 255-259, 2009

[37] S. Massa, F. Gardini, M. Sinigaglia, M. E. Guerzoni, 'Klebsiella pneumoniae as a Spoilage Organism in Mozzarella Cheese" Journal of Dairy Science, 75(6) 14111414,1992 